\title{
Atheism and discrimination in the face of contemporary changes in the world
}

\section{KEYWORDS}

atheism, New Atheism, discrimination, humanism

\begin{abstract}
Łopuszańska Urszula, Zacharska Adrianna, Gierszon Patrycja, Samardakiewicz Marzena, Atheism and discrimination in the face of contemporary changes in the world. Culture - Society - Education no. 1(17) 2020, Poznań 2020, pp. 289-297, Adam Mickiewicz University Press. ISSN 2300-0422. DOI 10.14746/kse.2020.17.12.2
\end{abstract}

The aim of this article is to present the situation of atheists around the world in the face of political and cultural changes in the world due to the increase in religious radicalism, particularly Islamic one, migration and terrorism. The article is of an illustrative character and presents the review of English literature in the scope of the discussed subject matter. Furthermore, the results of the latest global reports on prevalence of atheism in the world and the phenomenon of discrimination against persons not identifying with any faith: atheists, humanists or freethinkers were presented. The results of the selected, recent studies on the social perception of atheists and the phenomena of discrimination against them were shown. Another raised issue was the new social movement called New Atheism widespread mainly in the countries of the Western culture that in the future can constitute a new social and political challenge.

Conclusions: Between 2005 and 2012 the number of atheists increased by $3 \%$ and currently they constitute $13 \%$ of the population of the world, while the percentage of religious people decreased by $9 \%$. Atheists like other mi-

* ORCID https://orcid.org/0000-0001-6517-7577.

** ORCID https://orcid.org/0000-0002-2969-3280.

*** ORCID https://orcid.org/0000-0002-2793-0756. 
nority groups are discriminated against and their situation is dependent on the country in which they live. However, the vast majority of countries in the world violates the rights of persons identifying themselves as atheists. Still, in some countries, the declaration of atheism is forbidden, and in 13 countries the death penalty can be imposed.

\section{Introduction}

The beginning of the $21^{\text {st }}$ century brought new challenges for governments of countries around the world predominantly consisting in ensuring the security of citizens (Guild, 2009: 1-19). Nowadays, terrorism became a serious threat and many countries and nations in the world faced its deadly aspect. According to statistics, the largest number of people die as a result of terrorist attacks in countries such as: Iraq, Afghanistan, Nigeria, Pakistan (Global Terrorism Index, 2016). Despite the technological progress, which is rather related to the secularisation of societies, issues of faith and religion divided many social groups (Moberg, Partridge, 2017: 11-54). Religion became a tool to influence people and a kind of cover in political matters. New wars and military conflicts break out under the pretext of spreading religious aspects, the best example of which is the rule of the usurpatory Islamic State of Iraq and Syria (ISIS) (Shamieh, Zoltan, 2015: 363-378).

Recently, a lot of attention is given to the concept of Islamisation, that is, religious radicalism which is aimed at establishing a state following the sharia law (Machnikowski, 2016: 305). Under this pretext human and minorities rights are violated, including the right to express own religious and political views (Monshipouri et al., 2017: 1). It happens mainly in the Middle East, however, the issue of the religious radicalism and terrorism affects more and more countries in the world (Li et al., 2016: 175), also including Western culture countries. It has been proven with numerous terrorist attacks in Europe. In 2015, in France, only in one terrorist attack 148 persons were killed and 350 were injured. It is well-known that every now and then these attacks increase and take more and more victims (European Union Terrorism Situation and Trend Report, 2017).

Measures taken under the pretext of a religious movement and aimed at conquering new areas contributed to migration of people living in the territories entangled in the military and social conflict mainly to Western Europe (Wirth, 2016: 45).

It resulted in the increase in social unrest in the EU, which is proven with current governments made of populists, political parties of nationalistic character in some countries (Monshipouri et al., 2017: 1). 
Does the number of religious persons or the number of persons not identifying with any faith increase in the face of such events in the world? Can atheists help in mediations between parties to religious and cultural conflicts in the future? Are atheists discriminated against due to their non-engagement in religious matters? Authors of this article search for answers to these questions.

\section{Basic concepts}

In order to answer questions asked at the beginning, basic concepts in the area of religion and atheism should be explained. There are several definitions of atheism proposed by clergymen and laymen, and the simplest is the belief that there is no God or gods. In opposition to atheists there are theists who believe in the existence of God or gods (Cliteur, 2009). The "Oxford Dictionary" includes an explanation of the concept of an agnostic - "a person who believes that nothing is known or can be known of the existence or nature of God" (Oxford Dictionary a, 2017), they are opposed by gnostics who are convinced of the existence of God (Oxford Dictionary b, 2017).

Another concept frequently used in English publications is non-religion, (Nixon, 2020: 1). This term is usually associated with a lack of something metaphysical (religion). According to Lee (Lee, 2015: 32), the term "non-religion" should be used with regard to "emergence of something new". However, it can be said that non-religion is a broader category encompassing concepts, such as: naturalism (science, knowledge), humanism (human values, human rights, freedom), freethinking, scepticism, atheism (Hemming, 2017: 113-129), (Global Iindex of Religiosity, 2012).

\section{Religiosity and atheism in the world}

In the view of the Global Index of Religiosity and Atheism, in 2012, 59\% of people in the world described themselves as religious persons, $23 \%$ as non-religious, and $13 \%$ of persons admitted that they are atheists. Atheists are mainly concentrated in Asia and Europe and the list of ten most atheist countries included: China, Japan, the Czech Republic, France, South Korea, Germany, the Netherlands, Australia, Ireland. It should be noticed that the above study concerned own perception, perhaps participants' declarations not always reflected the actual state. Another compilation presented 10 countries, in which citizens described themselves as religious 
persons. In this case, these countries are spread around the world and they include: Ghana, Nigeria, Armenia, the Republic of Fiji, Macedonia, Romania, Iraq, Kenia, Peru, Brazil. It should be underlined that between 2005 and 2012 certain changes were noted that indicate that religiosity decreased by $9 \%$, whereas, the number of atheists increased by $3 \%$. Additionally, the atheism index is higher among persons with higher education, whereas, the religiosity index is higher among persons with lower incomes (Global Index of Religiosity, 2012).

\section{Are atheists discriminated against?}

The simplest definition of discrimination states that it occurs when one person treats the other unjustly, since he or she is a member of a different group. Such behaviours can be aimed at individuals or groups e.g. ethnic groups, in an open, direct or hidden manner (Whitley, Kite, 2009: 19).

The study has shown that high intensity of depression, lower intergroup competence are related to frequently experiencing discrimination from others (Phinney et al., 1998: 927). Persons with lower self-esteem are more often discriminated against, which results in even deeper psychological issues (Major et al., 2003: 147).

Results of discrimination against minorities are usually the same: worse learning conditions, difficulties with finding a job, especially on social positions, more difficult access to medical treatment, social and court injustice (Bond et al., 2010: 3).

It could seem that atheists as persons non-engaged in religious matters, believing in human rights, including moral rights, can evoke neutral feelings from religious persons. In the light of Article 18 of the Universal Declaration of Human Rights, everyone has the right to freedom of thought and beliefs as well as freedom to change them, including changing his or her religious beliefs. This right is binding as of 1948 (Universal Declaration of Human Rights, 1948). Is this right adhered to in the world? What is the actual image of the atheists' situation?

According to A Global Report on Discrimination Against Humanists, Atheists, and the Non-religious of 2015, atheists in the whole world experience discrimination even in highly developed countries (A Global Report on Discrimination..., 2017).

This report divides countries into five categories in terms of respecting the rights of atheists, humanists and freethinkers: (1) free and equal, (2) satisfactory, (3) systemic discrimination, (4) serious discrimination, (5) gross violations. In the view of this report, the situation was assessed as free and equal only in the 
following countries: Belgium, the Netherlands, Estonia, Kosovo, Taiwan, Nauru, the Republic of Fiji, Kiribati. Whereas, gross violations happened in: the Gambia, Mauretania, Nigeria, Swazi, the Comoros, Sudan, Libya, Egypt, Eritrea, Somalia, Ethiopia, Jordan, Saudi Arabia, Yemen, the United Arab Emirates, Qatar, Bahrain, Kuwait, Iraq, Syria, the United Arab Republic, Iran, Afghanistan, Pakistan, Bangladesh, the Maldives, China, Malesia, Indonesia, Brunei and North Korea. In the remaining countries systemic discrimination or serious discrimination were stated. In 55 countries blasphemy or offence against religious feelings are considered a crime entered into the legal code. In 39 of them the aforementioned act is punishable with a penalty of imprisonment. In EU states such as: Denmark, Germany, Greece, Hungary, Malta and Poland blasphemy is punishable with a penalty of imprisonment up to 3 years. It should be underlined that in some countries identifying as an atheist is still illegal. In 19 countries in the world it is punishable with a penalty and in 13 of them it is punished with death (A Global Report on Discrimination, 2017).

\section{What is the social image and receipt of atheists?}

A vast majority of studies in this scope come from the USA. In 2008, in the USA a research was conducted on the religious identification, American Religious Identification Survey (ARIS), on which quite a lot of studies are based. In the light of this report, $24 \%$ of persons identifying as non-religious were formally Catholics. In terms of ethnicity those were mainly Asians, Irish and Jews. $60 \%$ were men and $40 \%$ were women (Kosmin et al., 2008: 1).

$41 \%$ of atheists in the USA admitted that due to the lack of religious identification, in the last 5 years they experienced the following types of discrimination: slander, coercion, social ostracism, refusal to sell goods and services and hate (Hammer et al., 2012: 43).

What is interesting, the strongest discrimination predictor was not the theological atheism or agnosticism, but the identification as an atheist or agnostic (it concerned a situation when persons were asked about their religious identification). Remaining predictors included: age, country region, rural versus urban terrains, family's religious expectations, ethnicity and race. Persons expressing stronger views experienced discrimination to a larger extent (Cragun et al., 2012: 105).

The intercultural experiment conducted in Great Britain, China and Malesia (in the group of over 600 persons) with the use of 88 rounds of the binary version 
of the trust game showed that both, religious persons and atheists claimed that religious persons are more trustworthy. Furthermore, religious persons showed a tendency to trust persons from the same faith more. Religiosity was also connected with inclination to discriminate against non-religious persons (Chuah et al., 2016: 280).

In the next experiment conducted in a group of 618 persons, a character created by the authors, Jordan - a young man at the last year of architecture studies was used. Participants were divided into 4 groups and each group received the same description of Jordan, but with a different basic information that Jordan was: (1) an atheist, (2) without faith in God, (3) religious, (4) not married. Then, participants were asked to evaluate this person. Jordan obtained a higher number of negative assessments when he was identified as an atheist than when his religiosity was not mentioned or when he was identified as a religious person. No statistically significant differences were noted between description of an atheist and an expression: without faith in God. It resulted in participants negatively assessing the young boy created for the purposes of the research, who obtained a label of an atheist. According to authors, people react negatively to the statement - an atheist, since it triggers their specific reaction to the lack of faith in God. Therefore, one can conclude that faith aspects are more important in social perception of a person than his or her acts and values (Lawton \& Heesacker, 2012: 32).

\section{New Atheism as a challenge for politicians and societies}

New Atheism also known as "militant atheism" is a new anti-religious movement. An important role in the emergence thereof was played by the book The God Delusion by Richard Dawkins, which in 2006 was included in the list of bestsellers (Mcanulla, 2012: 91). The book presents facts, evidence on the non-existence of God and it also refers to the theory of evolution. It formulates a postulate that atheists can be happy and intellectually fulfilled, as well as moral. Being an atheist is a proof of having a healthy and independent mind. It expresses an opinion that children are judged through the prism of their parents' faith, which, according to the author, should not take place (Dawkins, 2016).

What are common features of new atheists? Usually, they do not affiliate with any political party. And if they do, they support liberal values and campaigns. In comparison with religious persons, contemporary atheists are usually young men with higher education and with higher incomes. Above all, they are non-conform- 
ists and in comparison with religious persons, they are more tolerant. Furthermore, they prove to be less authoritarian and less dogmatic than believers (Kettel 2013: 62).

In the face of their growing power, it can be expected that they will make (especially in some countries) quite a numerous group of persons not willingly participating in political life. However, the expression "combative" gives an impression that new atheists will demand their minority rights. The only question is, whether the rest of the society is ready?

\section{Summary}

Atheists, non-religious persons are persons believing in human rights; they often postulate humanistic values in life. They incite negative feelings in the majority of religious persons, which is proven with scientific experiments in this scope. The biggest difficulty for religious persons is to imagine that someone does not believe in God. It seems that it causes fear in some believers.

Atheists and non-religious persons, as other minorities, are discriminated against in the world, even in Western culture countries. It results in social problems, for instance, caused by the lack of access to secular schools, as well as psychological problems. Discrimination can contribute to lowering self-esteem, aggravation of depression.

An offence against religious feelings can involve a penalty of imprisonment and in the worst case scenario, atheists are even deprived of the right to exist. Their situation differs depending on the country they live in, however, the most difficult one is in the Middle East. In the $21^{\text {st }}$ century identifying as an atheist is still illegal. In 13 countries it is punishable with death.

In the face of views' radicalisation in the world resulting from, for instance, terrorism, an increase in the number of atheists in the world is visible. It seems that the atheism movement is growing and takes on the combative character, which is proven by the new atheism movement.

\section{Bibliography}

A Global Report on Discrimination Against Humanists, Atheists, and the Non-religious, (IHEU), (2015), http://iheu.org/newsite/wp-content/uploads/2015/12/FOT15-FULL-v0_2.pdf, accessed: 29.05.2017. Assembly U.G. (1948), Universal Declaration of Human Rights, UN General Assembly. 
Bond L., McGinnity F., Russell H. (2010), Introduction: making equality count, [in:] L. Bond, F. McGinnity, H. Russell (eds.), Making Equality Count: Irish and International Research Measuring Equality and Discrimination, Dublin, pp. 1-19.

Chuah S.H., Gächter S., Hoffmann R., Tan J.H. (2016), Religion, discrimination and trust across three cultures, European Economic Review, 90, pp. 280-301.

Cliteur, P. (2009), The Definition of Atheism, https://dspace2.creighton.edu/xmlui/handle/10504/64446, accessed: 31.05.2017.

Cragun R.T., Kosmin B., Keysar A., Hammer J.H., Nielsen M. (2012), On the receiving end: Discrimination toward the non-religious in the United States, Journal of Contemporary Religion, 27(1), pp. 105-127.

Dawkins R. (2016), The God Delusion, London.

European Union Terrorism Situation and Trend Report 2016, https://europol.europa.eu, accessed: 31.05.2017.

Global Terrorism Index 2016, (2016), Institute for Economics \& Peace, pp. 94-95, http://economicsandpeace.org, accessed: 31.05.2017.

Guild E., (2009), Security and Migration in the $21^{\text {st }}$ Century, Cambridge.

Hammer J., Cragun R., Hwang K., Smith J. (2012), Forms, frequency, and correlates of perceived anti-atheist discrimination, Secularism and Nonreligion, pp. 43-67.

Hemming P.J. (2017), Childhood, youth and non-religion: Towards a social research agenda, Social Compass, 64(1), pp. 113-129.

Kettell S. (2013), Faithless: The politics of new atheism, Secularism and Nonreligion, 2, pp. 61-67.

Kosmin B.A., Keysar A., Cragun R., Navarro-Rivera J. (2009), American Nones: The profile of the no religion population, a report based on the American religious identification survey 2008, Hartford.

Lawton S., Heesacker M. (2012), Anti-atheist bias in the United States: Testing two critical assumptions, Secularism and Nonreligion, 1, pp. 32-42.

Lee L. (2015), Recognizing the Non-Religious: Reimagining the Secular, Oxford.

Li Z., Sun D., ChenH., Huang S.Y. (2016), Identifying the socio-spatial dynamics of terrorist attacks in the Middle East, In Intelligence and Security Informatics (ISI), 2016 IEEE Conference on, pp. 175-180.

Machnikowski R.M. (2016), Terroryzm jako globalne zagrożenie XXI w., [in:] T. Domański (ed.), Międzynarodowe studia polityczne i kulturowe wobec wyzwań współczesności, Łódź, pp. 295-307.

Major B., Quinton W.J., Schmader T. (2003), Attributions to discrimination and self-esteem: Impact of group identification and situational ambiguity, Journal of Experimental Social Psychology, 39(3), pp. 220-231.

Mcanulla S. (2012), Radical atheism and religious power. New atheist politics, Approaching Religion, 2(1), pp. 87-99.

Moberg M., Partridge C. (2017), The study of religion and popular music: theoretical perspectives, methodologies and issues, [in:] C. Partridge, M. Moberg (ed.), The Bloomsbury Handbook of Religion and Popular Music, Bloomsbury, pp. 11-54.

Monshipouri M., Welch Jr C.E., Nikazmrad K. (2017), Protecting human rights in the era of uncertainty: How not to lose the war against ISIS, Journal of Human Rights, 16(1), pp. 1-24.

Nixon A.G. (2020), 'Non-religion' as part of the 'religion' category in international human rights, Religions, 11(79), pp. 1-18.

Oxford Dictionary a, (2017), https://en.oxforddictionaries.com/definition/agnostic, accessed: 29.05.2017. 
Oxford Dictionary b, (2017), https://en.oxforddictionaries.com/definition/gnosticism, accessed: 29.05.2017.

Phinney J.S., Madden T., Santos L.J. (1998), Psychological variables as predictors of perceived ethnic discrimination among minority and immigrant adolescents, Journal of Applied Social Psychology, 28(11), pp. 937-953.

Shamieh L., Zoltan S. (2015), The Rise of Islamic State of Iraq and Syria (ISIS), Defense Against Terrorism Review, 14(4), pp. 363-378.

Whitley B., Kite, M. (2009), The Psychology of Prejudice and Discrimination, Princeton.

WIN-Gallup International (2012), Global index of religiosity and atheism, http://www.wingia.com/ web/files/news/14/file/14.pdf Google Scholar, accessed: 5.05.2017.

Wirth T. (2016), The European Union's framing of the European refugee crisis, Elon Journal, pp. $45-56$. 
